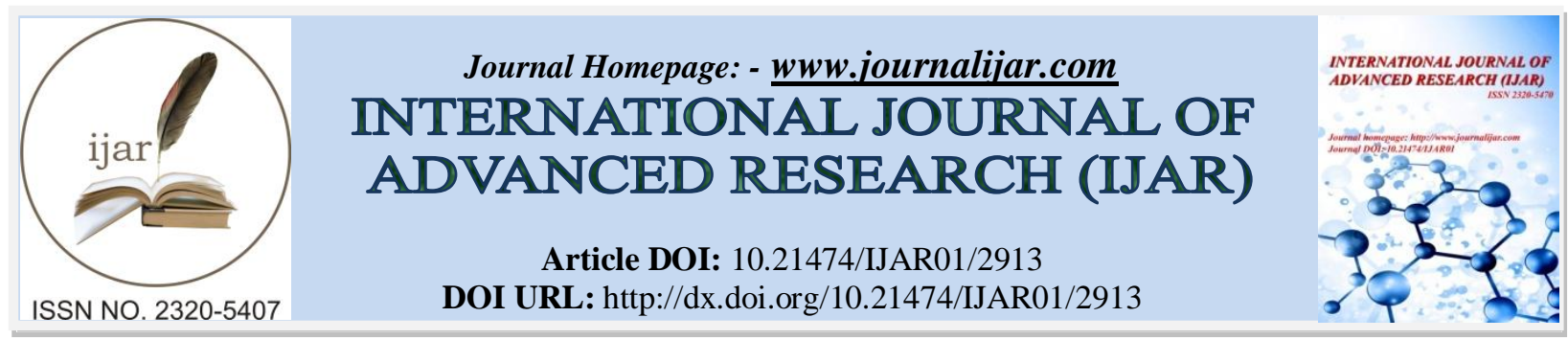

RESEARCH ARTICLE

\title{
ARE SOVEREIGN BONDS MORE RISKY THAN SOVEREIGN SUKUK? EVIDENCE FROM MALAYSIAN MARKET.
}

Rouetbi Emna ${ }^{1}$ and Chalghoum Ali $^{2}$.

1. Institut Superieur de Finance et Fiscalité Sousse, Rue 18 janvier Sousse, Tunisia.

2. Institut des Hautes Etudes Commerciales de Carthage, Tunisia.

\section{Manuscript Info}

\section{Manuscript History}

Received: 24 November 2016

Final Accepted: 25 December 2016

Published: January 2017

\section{Key words:-}

sovereign sukuks, sovereign bonds, size effect, value effect, TERM factor,

Malaysian market.

\begin{abstract}
The main objective of this paper is to compare sovereign Sukuk performance to classic sovereign bonds issued by the Malaysian government. This comparison focuses on the excess returns variations in reaction to factors as defined by Fama and Frensh (1993). Firstly, sukuks are more sensitive to each of the different factors of the model. Secondly, concerning size effect, small issuances outperform big ones; the opposite is available for bonds. Thirdly, a positive value effect relative to the factor HML is evidenced for Sukuk. However, we highlighted similarities regarding the reaction of both instruments to interest rates and market risk variations.
\end{abstract}

Copy Right, IJAR, 2016,. All rights reserved.

\section{Introduction:-}

Sukuks are considered as financial innovations representing a model of ethical finance (see Guéranger (2009)). Among the wide range of Islamic financial products we will be interested in sukuks which represent Islamic certificates of investment. The latter have experienced explosive growth. Global sukuk issuances in 2008 were about 24.264 billion $\$$ and increased almost twelve times to reach 290.6 billion\$ in 2015 . This enabled it to grab significant share of the market for fixed income instruments. This broad expansion is dominated mainly by sovereign and semisovereign issuances. Indeed, sovereign sukuk and government related entity issuances account for $70 \%$ versus $30 \%$ of corporate ones of total global issuances.

Miller, Challoner and Atta (2007), pointed out that the sukuk are Shariah ${ }^{1}$ compliant instruments that are very similar to conventional bonds. Despite the respected condition on the assets which must have no relation with illicit activities with the respect of Islam law. Sukuk are similar to traditional bonds in the commitment established between the subscriber and the issuer. Furthermore, the authors added that in practice the two financial instruments generate the same income value for their investors. The only difference is that, for sukuk, the investor receives returns on the underlying asset instead of the interest for conventional bonds.

Wilson (2008) also confirms that the sukuk have no remarkable divergences from conventional bonds, especially from a financial point of view. Certainly, investors feel more protected from risk when holding familiar instrument compared to another new one. In addition, for the sukuk rating, Wilson added that ordinary rating agencies use the

\footnotetext{
${ }^{1}$ Sharia is Islam law.
} 
same assessment methods as for traditional funding instruments ${ }^{2}$. In the same way, when considering G7 countries Kim and In (2007) have reached the same conclusions. This confirms the evidence on the similarity between Islamic and conventional instruments. Moreover, the shape of co-movement between Islamic assets and conventional bonds showed clearly that they behave in the same way even in terms of frequency and time.

Recently, Ahmad, and Radzi (2011) added that this similarity is clearer for "asset based sukuk" ${ }^{3 "}$. This result was confirmed by Naifar and Mseddi (2013). Although, the two instruments generate predictable returns; they differ in terms of sensitivity to economic and market conditions. They used a sample of issuances spread over a period of 20 years to identify the impact of GDP, the exchange rate, market liquidity on sukuk and bonds from the Malaysian market. The results showed that sukuk are sensitive to economic factors like GDP, Forex and international liquidity (reserves minus gold), while conventional bonds are only sensitive to Forex evolution. These results stipulate that the sukuks take into account the economic circumstances. Moreover, these authors noted that this impact is of minor importance compared to the bonds' one. In the same framework, Godlewski, Turk-Ariss, Weill (2010), pointed out that the sukuk are rather "asset-based" than asset- Backed ${ }^{4}$ "instruments, with underlying assets whose nature and area of activity are in accordance with Islamic law. The same research has shown that despite the similarity of sukuk with conventional shares, the sukuk are linked to a specific assets, services or projects during a specific time period unlike ordinary stocks representing a property right that concerns the whole company for an indefinite period.

A comparison of the investors' required returns for the two financial instruments with the same ratings and generating the same profits (coupons for conventional bonds) was performed by Ariff and Safari (2012). In other words, the latter used bonds and sukuks with the same duration, same issuer (sovereign, quasi-sovereign, corporate) rated AAA. Using the classical method for bond valuation the authors showed that required interest rates on the sukuk are different from those on conventional bonds. In addition, they recommended using two different methods for their assessments. Elsewhere,

They found that there was no relationship between the performance of Islamic sukuk and conventional bonds.

For the Malaysian market, Ramasamy et al (2011) compared sukuk to government bonds and corporate ones in terms of sensitivity, as measured by convexity and duration. The results show that sukuk are less risky compared to corporate bonds. In terms of profitability, the sukuk are more profitable. These results have allowed the authors to consider the sukuk as the best investment appropriate for risk adverse investors especially as the debt market is generally preferred by this kind of investors.

Moreover, Godlewski et al. (2010), Alam et al (2013), attributed negative market reaction to Sukuk's issuances against a positive one to conventional bonds to the investor's faculty to distinguish between the two financial instruments despite their structural similarity. Usmani (2007) showed that market participants perceive these instruments differently and their reactions to the issuance of these instruments are specific to one another. This research indicates a lack of a market significant reaction to issuance of conventional bonds against the evidence of a negative one to the Sukuk announcement. In other words Sukuk emissions have a negative effect on the market reflected by the negative value of the Sukuk's average cumulative abnormal returns.

Godlewski et al. (2010) explained this significant difference in market reaction between the issuance of sukuk and that of conventional bonds by adverse selection. According to the authors, only borrowers who predict low returns from their projects are motivated by the issuance of Sukuk because issuers must choose between a mandatory coupon payment without taking into account the conventional return and the principle based on sharing profits and losses. So if an entrepreneur predicts a low profit, he prefers financing based on profit and loss sharing to minimize its possible losses. And if he forecasts large profits, it becomes more interesting to be financed by conventional bonds. So Sukuk issuance presents a negative signal for investors about the company, since bad entrepreneur will

\footnotetext{
${ }^{2}$ Several Islamic rating agencies were dedicated to awarding Sukuk ratings, such as 'the Islamic Development Bank (IDB)" which has gained a lot of experience in this area, these institution still use the same criteria used by other conventional credit rating institutions.

${ }^{3}$ According to Patel (2013) for the asset-based Sukuk, the principal repayment is guaranteed by the issuer through the buy-back commitment and therefore the coupons are protected.

${ }^{4}$ For asset-backed sukuks, the principal is not guaranteed by the issuer and the coupons are therefore unprotected (the investor has no guaranteed income).
} 
choose this instrument which is badly perceived by investors. In the same context, Kuran (2004) advanced the same argument when he explained the reason that makes several Islamic banks no longer funding by financial instruments based on participatory bases (Moucharaka ${ }^{5}$, Moudharaba ${ }^{6}$ ). Because, in many countries where Islamic banks coexist with conventional ones when dealing with an adverse selection problem they use the following strategy: proposing conventional bond issuance when the anticipated profits of a project exceed a certain threshold, otherwise they offer sukuk issuance. This last choice is justified by the principle of sharing the losses with the subscribers.

Again, when defending the innovative vision of the Sukuk, Vishwanath and Azmi (2009) consider that the innovative principals of the Sukuk implies a higher exposure to certain financial market risks, especially credit and counterparty ones. Indeed, Sukuk issuers are largely found in emerging markets where counterparties have less sophisticated risk management mechanisms. On the other hand, Fathurahaman and Fitriati (2013) were interested in the Indonesian market. They compared Yield to Maturity (YTM) of both instruments for 10 Sukuk groups and bonds randomly built. The results showed that the YTMs of the Sukuks were higher than those of the conventional bonds.

On the other hand, Cakir and Raei (2007) showed that Sukuks present a different financial instrument compared to traditional bonds. They tested the issuance advantage of sovereign Sukuk in terms of risk and thus confirmed that they are alternative financial instruments to conventional bonds. Within a value-at-risk (VaR) framework and for portfolios of equal values, they found that the maximum loss decreases when adding Sukuks to portfolio of Eurobonds. This is explained not only by the fact that these instruments offer a diversification advantage for investors but also because of the different price behaviour of the two instruments. Hassan (2012) carried out the same methodology as Cakir and Raei (2007) they noticed a gain in the portfolios following diversification. However, within a Value at Risk (VaR) framework, the first study concluded that the Sukuk's built portfolio is more risky than the bonds' one. This contradicted the results obtained by Cakir and Raei (2007).

Blake, Elton, Gruber (1993) were interested on bonds and more specifically on bond funds. They agree that compared to stock returns, the latter are generally influenced by fewer factors.

Within market risk valuation framework, researches by Fama and French (1992a), Fama and French (1993) shows that market excess return relative to a risk-free asset is one of the explanatory variables influencing returns' variation of the considered asset. Indeed, an increase in this premium leads investors to require additional returns.

In the same vein we propose to verify the validity of the following assumptions:

H1: The Sukuk returns vary in the same direction as the market risk premium.

H2: Bond returns vary in the same direction as the market risk premium.

In addition, other risk premiums have been used in the financial literature such as size, value, interest rate variations (TERM). The latter is the difference between the return of long-term government bonds and short-term rates. Fama and French used the "mimicking portfolio" (SMB: small minus big) as a size factor proxy. They made a set of allocations of their sample to calculate this variable which expresses the size premium. Indeed, Bernoth, Hagen, Schuknecht (2012) used the issuance size of sovereign bonds for the European bond market. This variable presents an indirect measure of liquidity. They concluded that the larger the bond size, the higher is required return.

So the next hypotheses could be formulated as follows:

H3: Sukuks returns vary in the same direction with the size factor (SMB). H4: Bonds returns vary in the same direction with the size factor (SMB).

Another management style indicator used by Fama and French is the HML (High minus Low) which is the difference between the average of companies with a high book to market ratio and that of companies with the low ratio. Fama and French (1992a) found that firms with low market prospects have a high ratio and a high return, hence a low price of the stock. Conversely, firms with strong prospects have a low ratio and a low return. Hence, the positive relationship with the asset's return.

H5: The return of the Sukuks varies in the same direction as the value factor (HML).

\footnotetext{
${ }^{5}$ Moucharaka (contribution): A participatory contract stipulating the modality of each contribution and the repartition of profits and losses between different participants.

${ }^{6}$ Moudharaba: a partnership engaging two partners one provides capital and the other managing skills.
} 


\section{H6: Returns on bonds vary in the same direction as the value factor (HML).}

Fama and French (1993) argued that one of the common risk factors associated with bonds is relative to unexpected interest rate variation. Indeed the latter is inversely related to conventional bonds performance. According to Syamni and Husaini (2010) coupon rates are fixed but the present value of receivable cash-flows fluctuates negatively to interest rate variation.

As a result, investors and fund managers will constrain to sell long-term bonds at a reduced price in order to generate cash for redemptions.

Similarly, Bhattacharyay (2013) underlined a negative relationship between bond returns and interest rate variations. This is due to the reluctance of investors to invest in long-term bonds when interest rates fluctuate.

\section{H7: Bond returns are negatively related to the factor (TERM) representing the interest rate variation.}

Concerning the relationship between Sukuk and interest rate changes, Syamni and Husaini (2010), Said and Grassa (2013) have shown that there is no significant relation between Islamic bonds' returns and interest rate variations as Islamic law prohibits interest. The same result was made by Guyot (2008) through a comparison between the Islamic indices and the conventional ones. The author has found that Treasury Bill rate has less significant impact (even null) on the Islamic indices compared to the conventional ones as the Islamic indices are subject to a "specific filter" linked to the prohibition of the "'Riba ${ }^{7}$ ',

Although Islamic law prohibits interest in its undertakings, Elkarim (2012), Xian et al (2015) found that Sukuk returns present a significant and negative reaction to interest rate variations. Indeed, they pointed out a negative relationship between sukuk's revenue and the interest rate. The impact of interest rate variation on sukuk can only be indirect. As a consequence, the authors argued that this variable is a common economic indicator that affects affecting all financial instruments included the sukuk. Thus the following hypothesis:

\section{H8: Sukuk returns are negatively related to the interest rate (TERM) factor.}

\section{Data and Methodology:-}

The recent development of the Sukuk market in Malaysia over the last few years has allowed it to become the world preferred destination for attracting local and foreign investors interested in these innovative financial instruments. Consequently, in 2013 Malaysia accounts for 69\% of the world's issuances owing to the development of the necessary skills that have made this country a favourable ground for Islamic financial industries and services. The present paper fits in this framework. We propose to deal with sovereign issues since they are perceived as a benchmark in terms of stability for sovereign bonds. The relative returns variation is considered as an indicator of investor confidence in the government's solvency. Moreover we selected the sukuk and bonds of maturity 10 and 11 years. We chose to deal with daily frequencies spread over the period from 04 September 2013 to 30 April 2015 relative to 17 sukuks issuances and 10 bonds ones.

Table 1:- Descriptive statistics of returns for the two financial instruments:

\begin{tabular}{|l|l|l|l|l|l|}
\hline Instrument & ISIN & Mean & Min & Max & ST deviation \\
\hline \multirow{5}{*}{ Sukuk } & MYBZN1200011 & 4.21216204 & 3.878 & 4.539 & 0.13218201 \\
\cline { 2 - 6 } & MYBGO1300330 & 4.15286574 & 3.657 & 4.434 & 0.13993381 \\
\cline { 2 - 6 } & MYBGO1200373 & 4.13396296 & 3.77 & 4.419 & 0.1309147 \\
\cline { 2 - 6 } & MYBGO12037A2 & 4.07005556 & 3.638 & 4.419 & 0.13422361 \\
\cline { 2 - 6 } & MYBGN1100252 & 4.0651169 & 3.705 & 4.365 & 0.13555967 \\
\cline { 2 - 6 } & MYBGN11025A9 & 4.00697454 & 3.613 & 4.341 & 0.12268346 \\
\cline { 2 - 6 } & MYBGN1000213 & 3.97442477 & 3.675 & 4.2265 & 0.12747342 \\
\cline { 2 - 6 } & MYBGO0900015 & 3.87223611 & 3.615 & 4.103 & 0.10906711 \\
\cline { 2 - 6 } & MYBZO1200373 & 4.27471065 & 3.948 & 4.641 & 0.12648042 \\
\cline { 2 - 6 } & MYBZK1300221 & 4.05468519 & 3.733 & 4.3005 & 0.09701938 \\
\cline { 2 - 6 } & MYBGN1000601 & 4.00023843 & 3.6865 & 4.2885 & 0.12876654 \\
\cline { 2 - 5 } & MYBGO0900619 & 3.9468588 & 3.659 & 4.179 & 0.12349964 \\
\cline { 2 - 5 } & MYBGL12098A7 & 3.91220602 & 3.594 & 4.253 & 0.12911882 \\
\hline
\end{tabular}

\footnotetext{
${ }^{7}$ Riba is the perception of interest from an investment.
} 


\begin{tabular}{|l|l|l|l|l|l|}
\hline & MYBGL12021A9 & 3.86569444 & 3.5485 & 4.143 & 0.12287644 \\
\cline { 2 - 6 } & MYBGL11001A2 & 3.7381794 & 3.4835 & 4.029 & 0.10926755 \\
\cline { 2 - 6 } & MYBGN0700086 & 3.61708565 & 3.374 & 3.945 & 0.09950871 \\
\cline { 2 - 6 } Sovereign bonds & MYBGN0600195 & 3.51638773 & 3.282 & 3.7775 & 0.10704237 \\
\cline { 2 - 6 } & MYBMN0700027 & 3.47070949 & 3.263 & 3.7895 & 0.09290801 \\
\cline { 2 - 6 } & MYBMK1300062 & 3.83586806 & 3.4645 & 4.1415 & 0.12840149 \\
\cline { 2 - 6 } & MYBMO1200017 & 3.95365046 & 3.6115 & 4.285 & 0.15378612 \\
\cline { 2 - 6 } & MYBMN1300033 & 3.95576389 & 3.5865 & 4.3015 & 0.15331458 \\
\cline { 2 - 6 } & MYMO1500010 & 3.96196412 & 3.5865 & 4.2955 & 0.14411402 \\
\cline { 2 - 6 } & MYBMO05002S9 & 3.17552431 & 2.936 & 3.58 & 0.15238437 \\
\cline { 2 - 6 } & MYBMO0600019 & 3.34306944 & 3.0665 & 3.6935 & 0.11020445 \\
\cline { 2 - 6 } & MYBMK1100058 & 3.64240046 & 3.4015 & 3.9115 & 0.09650163 \\
\cline { 2 - 6 } & MYBMO0900021 & 3.7772037 & 3.481 & 4.047 & 0.11717725 \\
\cline { 2 - 6 } & MYBMO1100019 & 3.91056134 & 3.601 & & 0.147146 \\
\hline
\end{tabular}

All bonds mentioned above are domestic issues and provide fixed rate income.

Based on the ratings assigned by the Fitch rating agency, all of the broadcasts in our sample have the same notation as "A".

Price database of domestic Sukuk / domestic bonds were downloaded from Reuters. We used the following calculations to determine the daily performance of the two types of instruments:

Daily returns of the asset $\mathrm{i}$ at time $\mathrm{t}\left(R_{i, t}\right)$ were calculated using the formula: RETURN.TIME.ECHEANCE (liquidation, maturity, issue, rate, nominal value, base) available on the Excel software where:

Liquidation is the liquidation date of the bond.

Maturity represents the maturity date of the bond. It is the expiry date.

Issue is the issue date of the bond, expressed as a serial number.

Nominal value represents the price per unit of nominal value of 100 currency units.

Base is the type of the day counting base to use: Base Day Count.

As we have already mentioned, our research is interested in the comparison of the two instruments (Sukuk and Conventional bonds) in terms of return and risk.

In the majority of financial models that are concerned with asset performance measurement, one of the data used is the risk-free rate $\left(R_{f}\right)$. Academics and practitioners arbitrarily use either short-term or long-term government bonds as a proxy for risk-free securities.

However, and according to Bruner et al (1998) the majority of practitioners prefer long-term bonds: $70 \%$ of companies and financial advisors use T-bonds with a maturity of 10 years or more, while almost $10 \%$ use T-bills.

In the present research we will use the US T-bonds as the risk-free rate $\left(R_{f}\right)$. We have represented below a descriptive table of the T-bonds:

Table 2:- Descriptive statistics of the T-bonds:

\begin{tabular}{|l|l|l|l|l|l|}
\hline ISIN & $\begin{array}{l}\text { Maturity } \\
\text { benchmark }\end{array}$ & Amount & Coupon type & Coupon (\%) & Rating (Agency) \\
\hline US912796GH66 & 1 & 25000390800 & Fixed & N/A & AAA (Fitch) \\
\hline US912828K668 & 2 & 26095183100 & Fixed & 0,5 & $\begin{array}{l}\text { AAA (Fitch) Aaa } \\
\text { (Moody's) }\end{array}$ \\
\hline US912828XA31 & 3 & 24542959600 & Fixed & 1 & AAA (Fitch) \\
\hline US912828K585 & 5 & 35128097400 & Fixed & 1,375 & $\begin{array}{l}\text { AAA (Fitch) Aaa } \\
\text { (Moody's) }\end{array}$ \\
\hline US912828WZ90 & 7 & 29106083700 & Fixed & 1,75 & $\begin{array}{l}\text { AAA (Fitch) Aaa } \\
\text { (Moody's) }\end{array}$ \\
\hline US912828XB14 & 10 & 24543188500 & Fixed & 2,125 & AAA (Fitch) \\
\hline
\end{tabular}


Hereafter, we will focus on the variables that will be used in our econometric model inspired from Fama and French (1993).

Fama and French (1993) model uses as explained variable the profitability in excess relative to the risk-free investment: $\left(R_{i}-R_{f}\right)$.

On the other hand, the explanatory variables were: market profitability in excess relative to risk-free investment $\left(R_{m}-R_{f}\right)$, Small minus Big (SMB), High minus Low (HML) and a maturity premium (TERM). Based on the literature, the model will be expressed as follows:

$$
\left(R_{i}-R_{f}\right)=f\left(\left(R_{m}-R_{f}\right), S M L, H M L, T E R M\right)
$$

Excess profitability of the bond/sukuk $\left(R_{i}-R_{f}\right)$ :

Litterman and Scheinkman (1991) when identifying bond performance determinants, they found that, there are "other natural candidates" to play the role of the dependent variable. And the best choice is the excess return of the security relative to the risk-free rate calculated as the difference between the return of the instrument (bonds/Sukuks) and the risk-free rate for a given date.

Excess return of the market $\left(R_{m}-R_{f}\right)$ : is the difference between the average daily returns of bonds/Sukuk market and the risk-free rate.

The risk-free rate used is the US T-bonds corresponding to the daily term to maturity for each security.

The estimated bond market risk $\left(R_{m}-R_{f}\right)$ varies between $0.757 \%$ and $3.787 \%$ for the whole sample. The intraindividual variance (within) is equal to 0.08 , while the inter-individual variance (between) is equal to 0.64 on a total variance of 0.65 , and $98 \%$ of the total variance. Hence the importance of the individual dimension relative to the temporal dimension of this variable.

Table 3:- Descriptive statistics of the variable $\left(R_{m}-R_{f}\right)$ for Sukuks and bonds:

\begin{tabular}{|l|l|l|l|l|l|l|}
\hline \multicolumn{2}{|l|}{ Variable bonds } & Mean & St deviations & Min & Max & observations \\
\hline \multirow{3}{*}{$\left(R_{m}-R_{f}\right)$} & Overall & 2,205928 & 0,8079963 & 0,75755 & 3,78745 & $\mathrm{~N}=4320$ \\
\cline { 2 - 7 } & Between & & 0,8007581 & 1,244663 & 3,493616 & $\mathrm{n}=10$ \\
\cline { 2 - 7 } & Within & & 0,2750132 & 1,482721 & 3,354426 & $\mathrm{~T}=432$ \\
\hline Variable sukuk & Mean & St deviations & Min & Max & observations \\
\hline \multirow{3}{*}{$\left(R_{m}-R_{f}\right)$} & Overall & 2,238364 & 0,6258143 & 0,8675882 & 3,697559 & $\mathrm{~N}=7344$ \\
\cline { 2 - 7 } & Between & & 0,5586861 & 1,507482 & 3,405912 & $\mathrm{n}=17$ \\
\cline { 2 - 7 } & Within & \multicolumn{3}{l}{1,291665} & 3,275123 & $\mathrm{~T}=432$ \\
\hline
\end{tabular}

\section{Small minus Big (SMB) \& High minus Low (HML) variables:-}

These two variables represent the contribution of Fama and French (1992a). They showed that profitability of financial assets is not explained only by the market factor but other factors arising from behavioural finance are candidates.

SMB and HML are, by the way, two portfolios constructed as follows: firstly the bond and sukuk samples were subdivided into two subsamples ( $\mathrm{S}$ and $\mathrm{B}$ ) according to their sizes ( $\mathrm{S}$ for smallest capitalisations and B For the big capitalisation ones).

A second ranking was made on the basis of the average daily return. There results three groups: L (Low), M (Medium) and $\mathrm{H}$ (High) representing respectively $40 \%, 20 \%$ and $40 \%$ of the total sample.

There were six portfolios at the junction of the two previous rankings: SL (Small-Low), SM (Small-Medium), SH (Small-High), BL (Big-High). For example, the SL portfolio contains the smallest Sukuk (bonds) and the lowest average returns.

The explanatory variable reflecting the size premium factor (SMB) corresponds to the difference between the average profitability of the three small-cap portfolios (SL, SM, SH) and the average profitability of the three largecapitalization portfolios. 


$$
S M B=\frac{1}{3}\left[R_{S L}+R_{S M}+R_{S H}\right]-\frac{1}{3}\left[R_{B L}+R_{B M}+R_{B H}\right]
$$

The third explanatory variable reflecting the premium factor (HML) corresponds to the difference between the average profitability of the two portfolios of high average returns $(\mathrm{SH}, \mathrm{BH})$ and the average profitability of the two portfolios of low average returns (SL, BL):

$$
H M L=\frac{1}{2}\left[R_{B H}+R_{R H}\right]-\frac{1}{2}\left[R_{B L}+R_{S L}\right]
$$

Table 4:- Descriptive statistics for the SMB portfolio.

\begin{tabular}{|l|l|l|l|l|l|l|}
\hline Variable & Mean & St deviations & Min & Max & observations \\
\hline \multirow{4}{*}{ Bonds } & Overall & 0.2734078 & 0.0729897 & 0.11325 & 0.4461667 & $\mathrm{~N}=4320$ \\
\cline { 2 - 7 } & Between & & 0 & 0.2734078 & 0.2734078 & $\mathrm{n}=10$ \\
\cline { 2 - 7 } & Within & & 0.0729897 & 0.11325 & 0.4461667 & $\mathrm{~T}=432$ \\
\hline \multirow{4}{*}{ Sukuk } & Overall & -0.1810376 & 0.0415897 & -0.2756667 & 0.51025 & $\mathrm{~N}=7344$ \\
\cline { 2 - 7 } & Between & & 0 & -0.1810376 & -0.1810376 & $\mathrm{n}=17$ \\
\cline { 2 - 7 } & Within & & 0.0415897 & -0.2756667 & -0.063 & $\mathrm{~T}=432$ \\
\hline
\end{tabular}

The size premium for bonds varies between 0.11325 and 0.4461667 for the whole sample. Its average value is of the order of 0.2734078 . The intra-individual variance (within) is equal to 0.01 , whereas the inter-individual variance (between) almost null. As the SMB variable, we note that the total variance of SMB is explained, entirely, by the intra-individual one (within). This proves the importance of the temporal dimension of this variable compared to the individual one.

For the Sukuk population the size premium (SMB) varies between -0.2756667 and 0.51025 for the whole sample. Its mean value is of the order of -0.1810376 . The intra-individual variance (within) is equal to 0.002 , whereas the interindividual variance (between) is null. As for bonds, we notice that the total variance is entirely explained by the intra-individual variance (within).

Table 5:- Descriptive table of the HML variable for Sukuk Variable

\begin{tabular}{|c|c|c|c|c|c|c|}
\hline \multicolumn{2}{|c|}{ Variable } & Mean & St deviations & Min & Max & observations \\
\hline \multirow{3}{*}{ Bonds } & Overall & 0,4450804 & 0,1209728 & 0,228375 & 0,731375 & $\mathrm{~N}=4320$ \\
\cline { 2 - 6 } & Between & & $5,85 \mathrm{E}-17$ & 0,4450804 & 0,4450804 & $\mathrm{n}=10$ \\
\cline { 2 - 7 } & Within & & 0,1209728 & 0,228375 & 0,731375 & $\mathrm{~T}=432$ \\
\hline \multirow{3}{*}{ Sukuk } & Overall & 0,3505561 & 0,0527164 & 0,21825 & 0,51025 & $\mathrm{~N}=7344$ \\
\cline { 2 - 7 } & Between & & 0 & 0,3505561 & 0,3505561 & $\mathrm{n}=17$ \\
\cline { 2 - 7 } & Within & & 0,0527164 & 0,21825 & 0,51025 & $\mathrm{~T}=432$ \\
\hline
\end{tabular}

The value premium HML for the Sukuk population has a minimum value of 0.21825 and a maximum of 0.51025 for the whole sample. Its mean value is about 0.3505561 . The intra-individual variance (within) is equal to 0.03 , while the inter-individual variance (between) is null. We note that the total variance of HML is explained by the intravariance (Within). This proves the importance of the temporal dimension of the HML variable. This result is available for bonds.

\section{Term:-}

The unexpected variance of the interest rate presents one of the risk factors for bonds. Our proxy for this factor is the TERM variable which is the difference between the daily performance of Sukuk / bonds and the U.S. Treasury-Bill yield of 3 months. The descriptive analysis of this variable on Stata 11 gave the following tables:

Table 6:- Descriptive statistics for the variable TERM:

\begin{tabular}{|l|l|l|r|r|r|l|}
\hline Variable & \multicolumn{1}{l|}{ Mean } & St deviations & \multicolumn{1}{l|}{ Min } & Max & observations \\
\hline \multirow{3}{*}{ Bonds } & Overall & 3.674705 & 0.299041 & 2.8805 & 4.2635 & $\mathrm{~N}=4320$ \\
\cline { 2 - 7 } & Between & & 0.2839073 & 3.147558 & 3.933998 & $\mathrm{n}=10$ \\
\cline { 2 - 7 } & Within & & 0.129868 & 3.289207 & 4.073147 & $\mathrm{~T}=432$ \\
\hline \multirow{3}{*}{ Sukuk } & Overall & 3.937537 & 0.2305956 & 3.2555 & 4.597 & $\mathrm{~N}=7344$ \\
\cline { 2 - 7 } & Between & & 0.2012848 & 3.488421 & 4.246591 & $\mathrm{n}=17$ \\
\cline { 2 - 7 } & Within & & 0.1226249 & 3.437638 & 4.292081 & $\mathrm{~T}=432$ \\
\hline
\end{tabular}


It's important to note that we applied the Spearman test to ensure that there is no correlation between the different variables.

\section{Fama and French (1993) Model:-}

In what follows we propose to estimate the Fama and French model (1993). This framework represents a multiple linear regression of the variable to be explained (the excess return) and the explanatory ones such: the market excess return, size premium, the value premium, the interest rate variation proxy.

$$
\left(R_{i, t}-R_{f, t}\right)=\beta_{0}+\left(R_{m, t}-R_{f, t}\right) \beta_{i}+S M L_{t} \beta_{s, i}+H M L_{t} \beta_{h, i}+T E R M_{t} \beta_{d, i}+\varepsilon_{i, t}
$$

$R_{i, t}$ is the return of the asset $\mathrm{i}$ for time $\mathrm{t}$;

$R_{f, t}$ is the risk-free at time $\mathrm{t}$;

$\beta_{0}$ is a constant;

$R_{m, t}$ is the market return at time t;

$\varepsilon_{i, t}$ is white noise;

SMB: is the risk premium generated by the size factor;

HMB: is the risk premium relative to the value risk factor;

TERM: is the premium relative to the term structure of interest rates.

\section{Estimation results and interpretation:-}

Considering the model presented above and with the respect of the brief literature review, we could expect the same behaviour of sukuk and bonds toward every explicative variable. However, estimation results presented here after couldn't confirm all of the research hypotheses.

Estimation results are reported in table 7.

In fact and according to table 7, the coefficient $\beta_{i}$ relative to excess market returns is positive and close to 1 for both instruments. In other words, a $1 \%$ change in market excess returns results in a variation of $0.886 \%(0.866 \%)$ of the return of the Sukuk (bonds).

Therefore, Bonds and sukuk are very sensitive to market return variations.

Table 7:- Estimation results.

$\left(R_{i, t}-R_{f, t}\right)=\beta_{0}+\left(R_{m, t}-R_{f, t}\right) \beta_{i}+S M L_{t} \beta_{s, i}+H M L_{t} \beta_{h, i}+T E R M_{t} \beta_{d, i}+\varepsilon_{i, t} \quad$ where $R_{i, t}$ is the return of the asset $\mathrm{i}$ at time $\mathrm{t} ; R_{f, t} i$ s the risk-free at time; $\beta_{0}$ is a constant; $R_{m, t}$ is the market return at time $\mathrm{t}$; $\varepsilon_{i, t}$ is white noise; SMB: is the risk premium generated by the size factor; HMB: is the risk premium relative to the value risk factor; TERM: is the premium relative to the term structure of interest rates. And $\mathrm{i}=\mathrm{Sukuk} /$ Bonds.

\begin{tabular}{|c|c|c|}
\hline Coefficient & Sukuk & Bonds \\
\hline$\beta_{0}$ & $\begin{array}{c}-2.089876 \\
(0.00)\end{array}$ & $\begin{array}{c}-1.798089 \\
(0.00)\end{array}$ \\
\hline $\boldsymbol{\beta}_{i}$ & $\begin{array}{c}0.8866522 \\
(0.00)\end{array}$ & $\begin{array}{c}0.8661735 \\
(0.00)\end{array}$ \\
\hline $\boldsymbol{\beta}_{s, i}$ & $\begin{array}{c}0.7242783 \\
(0.00)\end{array}$ & $\begin{array}{c}-0.106433 \\
(0.00)\end{array}$ \\
\hline $\boldsymbol{\beta}_{h, i}$ & $\begin{array}{c}0.2082551 \\
(0.00)\end{array}$ & $\begin{array}{c}-0.151512 \\
(0.00)\end{array}$ \\
\hline $\boldsymbol{\beta}_{d, i}$ & $\begin{array}{c}-0.610277 \\
(0.00)\end{array}$ & $\begin{array}{c}-0.595921 \\
(0.00)\end{array}$ \\
\hline
\end{tabular}

Taken together and in absolute value, all model parameters are higher for sukuks than for bonds. This shows the excess of sensitivity of the first instrument to different risk factors.

The excess market return $\left(R_{m, t}-R_{f, t}\right)$ is considered as a risk premium representing additional return required by the market for the extra risk taking compared to a risk-free investment.

When a market risk premium increases, investors require additional returns that will allow them to hedge market risk. Hence, the confirmation of hypotheses 1 and 2. 
As far as, the slight sensitivity of the Sukuk's excess return to the market risk premium $\left(\boldsymbol{\beta}_{\text {Sukuk }}>\boldsymbol{\beta}_{\text {Bonds }}\right)$ reflects the risky nature of this instrument compared to bonds. Indeed, being prohibited by the precepts of "Sharia", any negotiation of the debt is prohibited in the commitments of the Sukuk. This makes sukuk issuers prone to default.

For the SMB variable, the two financial instruments differ widely from one another. Indeed, for Sukuk a $1 \%$ change of the SMB variable leads to a variation of $0.72 \%$ in Sukuk performance. However, for bonds, the latter is about $0.11 \%$. This difference is also detected when returns are regressed separately on the size indicator variable (SMB). Consequently, we can say that Sukuk returns are more sensitive to liquidity factor as measured by size.

Also positive $\beta_{s, \text { sukuks }}$ coefficient show that sukuk returns vary in the same direction of size factor. In other words, the smaller the size of sukuk is, the higher the perceived return becomes. Small issuance of sukuk sends a positive signal on the presence of counterparts in the Malaysian market.

Hypotheses 3 supposing a sukuks return variation of the same meaning with the SMB, is verified.

Surprisingly, the coefficient $\beta_{\mathrm{s}, \text { Bonds }}$ is of opposite sign for bonds indicating a negative reaction of excess returns to size factor increase (SMB). This factor is always related to momentum phenomena stipulating that small capitalisation stocks (bond) over perform big ones (see kent Hirshleifer and Subrahmanyam (1998)). However, when the opposite sign is observed this theory is thwarted. Thus and in the bases on the study of Burmeister, Roll and Ross (2003) we can say that big capitalisations outperform small ones especially in the case of an economic recession. Small issuances are more sensitive to market conditions.

This result clearly rejects hypothesis 4 .

As in Fama and French (1993) we consider the book to market (Book value/market value) and the HML factor in the same way as "YTM" as indicators of financial distress. We noticed that Sukuks with downward trending prices have a high "YTM" and positive HML coefficients.

Concerning bonds, the positive impact of the HML portfolio and the explained variable is not supported. Indeed, a $1 \%$ increase in HML results in a decrease in excess bond return of $0.1515 \%$. This leads to reject hypothesis 6 of the positive relation between these two variables. This result confirms those of Fama and French (1992b) pointing out that investors are actively hedging against the value risk represented by HML portfolio. We also notice that the latter contributes poorly to bonds' price variation (only $0.1515 \%$ of the performance in excess).

Contrariwise, table7 reports a positive impact of HML portfolio on the excess return of sukuks. In fact, a $1 \%$ increase of this factor leads to $0.208 \%$ increase of the sukuk excess return. Firstly, the impact in absolute value of HML on returns is twice as high for sukuks as for bonds. Then, this variable contributes more in explaining relative returns. Secondly, the negative value of $\beta_{h, \text { Sukuk }}$ shows that there is some profits opportunity to realise when buying undervaluated sukuks (high $\mathrm{B} / \mathrm{M}$ ) and selling the over valuated ones (low $\mathrm{B} / \mathrm{M}$ ).

Thus, we can confirm the positive impact of the HML factor on excess returns for sukuks introduced by the $5^{\text {th }}$ hypothesis.

The last variable in our model is TERM proposed by Fama and French (1993) as an extension of Fama and French (1992a). It reflects the market interest rate variation namely the difference between Sukuk (bonds) returns and the 3 months Treasury rate.

The Sukuk-specific model shows a significant effect at the $1 \%$ threshold of the Sukuk performance variable. This result urges us to confirm hypothesis 8 which assumes that the Sukuk are negatively influenced by interest rate variations (see Syamni et al (2010) and Said and Grassa (2013)). As in Elkarim (2012) and Xian et al (2015), we can say that Interest rate variation affects indirectly the performance of sukuks as it represents a common economic indicator for financial assets.

In addition, TERM factor highly and negatively contributes to relative sukuk returns variation at about $-0.61 \%$ for $1 \%$ variation. Bonds excess returns have the same meaning with respect to the TERM variation: an increase in the interest rate of about $1 \%$ results in a returns' decrease of $0.5959 \%$. 
These results could be interpreted in two ways: firstly, sukuk and bonds returns are very sensitive to business condition variations as specified by Fama and French (1993). Secondly, and according to Bhattacharyay (2013) investors are reluctant to invest in long term sukuks/bonds when interest rates increase as they predict a decrease of their purchasing power of long term fixed-rate bonds/Sukuk. Hence, the decline in demand for both instruments. This leads to a decrease in their returns.

Taken together, the last two results, are consistent with the literature review cited above, this leads us to confirm hypotheses 7 and 8 .

\section{Conclusion:-}

This paper sheds the light on differences between Sukuks and conventional bonds. Focusing on sovereign ones we have showed that investors perceive differently these two financial instruments.

Firstly, Sukuks are slightly more risky than bonds since relative underlined asset value isn't guaranteed at maturity. On the other side, interest on bonds and principal pay back are fixed beforehand.

Secondly, with respect to SMB factor, sukuks and bonds returns present variations of opposite sign. The first reacts positively leading to better performance of small issuances. And the latter reacts negatively to the size factor increase; hence big bond issuances outperform small ones.

Concerning value premium (HML factor), its contribution in absolute value to sukuk performance is twice that of bonds. However, a negative impact for bonds testifies that investors are actively hedging against the value risk. An effect of a contrary sign is valid for the sukuk showing that there is some profits opportunity to realise when buying undervaluated sukuks (high $\mathrm{B} / \mathrm{M}$ ) and selling the overvaluated ones (low $\mathrm{B} / \mathrm{M}$ ).

Nevertheless, toward interest rate variation, both instruments show negative reactions despite that by construction sukuk returns should be disconnected from. Then we can say that as well as bonds, sukuks are sensitive to changes in market conditions and business environment.

Indeed, the Sukuks show a performance higher than bonds throughout the analysis period. Based on a test of the averages of returns averages and risk premium, we confirmed the difference between the two financial instruments ${ }^{8}$.

\section{References:-}

1. Alam, N., Hassan, M. K., Haque, M. A., 2013, Are Islamic bonds different from conventional bonds? International evidence from capital market tests, Borsa Istanbul Review, 13, 3, $22-29$.

2. Ahmad W., Radzi R.M., 2011, Sustainability of Sukuk and Conventional Bond during Financial Crisis: Malaysia"s Capital Market, Global Economy and Finance Journal, pp 33-45.

3. Ariff A. et Safari M. , 2012, Are Sukuk Securities the Same as Conventional Bonds?, Afro Eurasian Studies, pp. 101-125

4. Bernoth. K, Hagen. J.V, Schuknecht. L, 2012, Sovereign risk premiums in the European government bond market, Journal of International Money and Finance, 31,5, 975-995.

5. Bhattacharyay,B.N. ,2013, Determinants of bond market development in Asia ,Journal of Asian Economics, 24, 124-137.

6. Blake C. R., Elton J.E., Gruber M.J.,1993, The Performance of Bond Mutual Funds, Journal of Business, 371403.

7. Bruner, R.F., Eades, K.M., Harris, R., Higgins, R.C., 1998, Best practices in estimating the cost of capital:survey and synthesis. Financial Practice and Education, 8, 13-28.

8. Burmeister E., Roll R., and Ross S.A., 2003, Using macroeconomic factors to control portfolio risk, working paper, BIRR, March 2003.

9. Cakir, S., Raei, F., 2007, Sukuk vs. Eurobonds: Is there a difference in value-at-risk?, IMF Working Paper, No. WP/07/237. Washington, DC: International Monetary Fund.

\footnotetext{
${ }^{8}$ We didn't report the estimate results in order to save the space.
} 
10. Elkarim, B. , 2012, Factors influence Sukuk and conventional bonds in Malaysia, Global Economy and Finance Journal, 3-14.

11. Fama E. F. and French K. R. ,1992a, The cross-section of expected stock returns. Journal of finance, 427- 465.

12. Fama E. F. and French K. R. ,1992b, The economic fundamentals of size and book-to-market equity, Working paper: Graduate School of Business. University of Chicago.

13. Fama E. F. et French K. R., 1993, Common risk factors in the returns on stocks and bonds, Journal of financial economics, 3-56.

14. Fathurahman H. et Fitriati R. ,2013, Comparative Analysis of Return on Sukuk and Conventional Bonds, American Journal of Economics, 159-163.

15. Godlewski, C. J., Turk-Ariss, R., Weill, L., 2010, Are sukuk really special? Evidence from the Malaysian Stock Exchange, BOFIT Discussion Papers, 6, 2011, Helsinki: Bank of Finland.

16. Grassa, R., Gazdar, K. ,2012, The determinants of the development of the Sukuk market in GCC countries, International Conference on Islamic Capital Markets, Bapepam-LK and IRTI - IDB, Indonesia.

17. Guéranger. F, 2009,Finance islamique, une illustration de la finance éthique, Dunod editions, 2009-08-26

18. Guyot A., 2008, Les préceptes de la Shari 'ah contribuent-ils à l'efficience et à la performance des marchés d'actions? Une étude comparative des indices Dow Jones Islamic, Colloque international: Ouverture et émergence en Méditerranée, 17-18 octobre, Rabat, Maroc.

19. Hassan, K. A. ,2012, Comparison between Sukuk and conventional bonds: Value at risk approach, Master thesis, Westminster University, UK. http://dx.doi.org/10.2139/ssrn.2215194.

20. Kent.D, Hirshleifer .D and Subrahmanyam. A ,1998, Investor psychology and security market under- and overreactions, Journal of Finance 53, 1839-1885.

21. Kim S., et In F. , 2007, On the relationship between changes in stock prices and bond yields in the G7 countries: A wavelet analysis, Journal of International Financial Markets, Institutions and Money, 167-179.

22. Kuran T., 2004, "Islam and Mammon", Princeton University Press.

23. Miller N.D., Challoner J. Atta A., 2007, UK Welcomes the Sukuk, International Financial Law Review, 24-25.

24. Naifar N., Mseddi S., 2013, Sukuk spreads determinants and pricing model methodology, Afro-Asian Journal. Finance and Accounting, 3,3, 241-257.

25. Ramasamy, R., Munisamy, S., Helmi, M. H. M. , 2011, Relative risk of Islamic sukuk over government and conventional bonds, Global Journal of Management and Business Research, 11, 6, 4-12.

26. Said A, Grassa R, 2013, The Determinants of Sukuk Market Development: Does Macroeconomic Factors Influence the Construction of Certain Structure of Sukuk? Journal of Applied Finance \& Banking, 3, 5, 2013, 251-267.

27. Syamni, G., Husaini. ,2010, Interest rates and currencies effect on Islamic and conventional bonds, Economic Journal of Emerging Market, 2 ,2, 29-140.Usmani M.T, 2007, Sukuk and their contemporary applications, Translated from the original Arabic by Sheikh Yusuf Talal DeLorenzo, AAOIFI Shari'a Council meeting, Saudi Arabia.

28. Vishwanath, S. R., Azmi, S. ,2009, An overview of Islamic șukūk bonds, The Journal of Structured Finance, $14,4,58-67$.

29. Wilson R., 2008, Innovation in structuring of sukuk securities, Humanomics, 170-181.

30. Xian L.J., Leong R.LLH, Chun W.K., Yee W.S., WeY.J. ,2015, Comparison between performance of sukuk and conventional bond in Malaysia, Faculty of Business and Finance, Department of Finance, April 2015. 